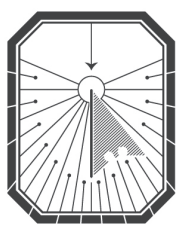

KYIV-MOHYLA

LAW \& POLITICS JOURNAL

KYIV-MOHYLA SCHOLARLY PEER-REVIEWED JOURNALS

The Separatism of Chechnya in 1991: Prerequisites for the Republic's Secession from Russia

Author(s): Ruslan Kermach

Source: Kyiv-Mohyla Law and Politics Journal 2 (2016): 203-216

Published by: National University of Kyiv-Mohyla Academy

http://kmlpj.ukma.edu.ua/ 


\title{
The Separatism of Chechnya in 1991: Prerequisites for the Republic's Secession from Russia
}

\author{
Ruslan Kermach \\ National University of Kyiv-Mohyla Academy, \\ Political Science Department
}

\begin{abstract}
The article deals with the case of Chechen separatism, which resulted in the secession of the Republic from Russia in 1991. The theoretical framework for this study is based on considering secession as a dynamic process triggered by a shift in the perception of a cost-benefit equilibrium regarding a possible attempt at secession. The second section of the article briefly analyzes the most important structural prerequisites, which could have been conducive for Chechen secessionism at the beginning of the 199os. The last section explains the factors, which could have been crucial in changing the initial calculation of a costs and benefits equilibrium regarding the possible attempt at secession. Among the above mentioned factors, the rise of ethno-nationalism and nationalist elites creating discourse justifying the secession of the Chechen Republic. The role of the center-periphery relationship and the weakening position of the federal center in Moscow are also considered in the article.
\end{abstract}

Key Words: secession, separatism, Chechnya, self-determination, cost-benefit, ethno-nationalism.

\section{Introduction}

The collapse and further demise of the Soviet Union (USSR) in 1991 ignited some ethnopolitical conflicts driven by nationalist movements in the former Union republics (SSR) and their autonomous subjects. Some of these conflicts were resolved in a non-violent way, others went through a rather prolonged violent resolution process (Nagorno-Karabakh, Abkhazia, Chechnya). Despite the fact that the demise of the USSR was instigated mainly by republican national political elites of some constituent units of the state (SSRs), the territorial autonomy of ethnic minorities within the Union republics (so called ASSRs) was also a factor that created some of the prerequisites for internal inter-republican separatism. ${ }^{1}$

The central and largest unit of the former Soviet Union - the RSFSR (Russian Soviet Federal Social Republic) inherited a "built-in territorialization of ethnicity in the federal structure" from the territorial-administrative division of the USSR. ${ }^{2}$ As a result, having around 20 autonomous

$1 \quad$ See Svante E. Cornell, "Autonomy as a Source of Conflict: Caucasian Conflicts in Theoretical Perspective," World Politics 54.2 (2002): 245-76.

2 James Hughes, “Chechnya: The Causes of a Protracted Post-Soviet Conflict," Civil Wars 4.4 (2001): 16. 
republics in its federal territorial structure, on the eve of its independence of the early 199os the Russian Federation faced an existential challenge, with some of these federal units demonstrating rather strong aspirations towards self-determination and even separatism (as, for example, the republics of Tatarstan, Tuva, Chechnya). ${ }^{3}$

The case of Chechnya is one of the most challenging examples of outright secessionism in the modern history of Russia (since 1991). The Chechen Republic is still regarded by many scholars as a potentially threatening region for Russia's territorial integrity. Much historical, ethnographical, and political research dealing with the case of Chechen separatism, addressing the roots of the protracted ethno-political conflict in the Caucasus, especially the roots of the First Chechen War for self-determination (1994-1996), has been done by prominent Russian (Tishkov, Gakaev, Popov) as well as foreign (Hughes, Schaefer, Pain) scholars. However, objectively less research is focused on the peculiarities of the very Chechen case as an example of the only Russian autonomous republic that rejected compromise on its future status as a federal unit and decided to fully secede instead.

In his statistical study Henry Hale provides us with evidence that "high levels of autonomy tend to encourage ethnically defined regions to declare sovereignty more quickly." ${ }^{4}$ But this evidence does not provide us with the answer to the question of why a strong outbreak of separatist tendencies occurred in, for instance, Tatarstan as well as in Chechnya, but not in Kabardino-Balkaria or the Republic of Dagestan, which formally had the same autonomous status within Russia (at the time the RSFSR). Or going further: why did the federal center in Moscow manage to keep the rebellious Republic of Tatarstan in the federation, but not the Chechen Republic, which decisively sought full independence, meaning full secession from the Russian federal state? Explaining the causal mechanisms that made Chechen secession from Russia possible at the beginning of the 199os is the main focus of analysis in the proposed study.

\section{Theoretical Framework: Cost-Benefit Equilibrium Regarding the Possibility of Secession}

According to Donald Horowitz's definition, secession "is an attempt by an ethnic group claiming a homeland to withdraw with its territory from the authority of a larger state of which it is a part."5 Another scholar, James Crawford, points out inter alia that secession "requires the opposition of the host state and the use or threat of force by the secessionist movement." 6 From the above mentioned definitions one might conclude that secession is not an instant event but rather a dynamic process through which specific "distinct communities" either gradually or more

3 Elise Giuliano, Constructing Grievance: Ethnic Nationalism in Russia's Republics (Ithaca, NY:

Cornell University Press, 2011).

4 Henry E. Hale, “The Parade of Sovereignties: Testing Theories of Secession in the Soviet Setting,"

British Journal of Political Science 30.1 (2000): 31.

5 Donald Horowitz, "Irredentas and Secessions: Adjacent Phenomena, Neglected Connections," International Journal of Comparative Sociology 32.1-2 (1992): 119.

6 Aleksandar Pavkovic and Peter Radan, The Ashgate Research Companion to Secession (Burlington: Ashgate Publishing Company, 2001), 4. 
intensively move towards self-determination and creating a fully independent sovereign state. Some constituent units of the host state may claim their right to political self-determination for durable periods of time and may suspend the process at the stage that provides them with only partial sovereignty within the limits of wider autonomy. The latter is illustrated, for instance, by the case of the Republic of Tatarstan in Russia. ${ }^{7}$

In explaining the dynamics of secession it is possible to apply the theoretical framework proposed by Viva Ona Bartcus, who explained secession as a process that arises when the "distinct community" determines that there has been a shift in the balance of some variables that measure the approximate costs and benefits of secession, on the one hand, and the costs and benefits of further membership in the host-state respectively. ${ }^{8}$ Generally, the framework elaborated by V. Bartcus is structured around 4 primary variables: (1) the benefits of continued membership in the larger existing political entity (host-state); (2) the costs of the secession attempt; and (3) the costs of membership in the host state; (4) the benefits of secession from the host-state. Whereas variables (1) and (2) may be viewed as factors constraining the possible secession attempt, variables (3) and (4), on the contrary, in case of a drastic increase of their "indicators," make the secessionist dynamic highly probable if not inevitable. The latter is true especially in such cases as the emergence of direct threats to the life of an ethnic community or threats to its national culture.

It is possible to infer from the above presented theoretical framework that secession will rather not be attempted when the perception of possible costs for such an attempt is too high (possible suppression or military intervention initiated by the host state in response) and when membership in the host state provides a community with some valuable economic benefits, revenues, or security guarantees. Thus the balance between variables (1) and (2) on the one hand, and variables (3), (4), on the other, as well as the prevalence of "constraining variables" (1) and (2) provides the host-state with some internal stability and makes secessionist dynamics in it unlikely. The situation may evolve into a "secession crisis" when the discontented community perceives a substantial rise in possible benefits that secession brings for them or regards further membership in the host state as unbearable, which makes secession a "last resort" alternative.

Applying this calculative rationalist approach to the empirical case of this article, it is possible to formulate the general hypothesis that the secession of the Chechen Republic (Ichkeria) was determined by the changing perception of the costs-benefits of secession in comparison to the possibility of remaining a part of the Russian Federation. In other words, this means that the variables motivating or instigating secessionist aspirations in the context of the Chechen case have substantially increased while those variables constraining the secession of the Republic on the contrary, have decreased.

The Republic of Tatarstan, which was a constituent part of Russia, demonstrated strong secessionist tendencies, but after the negotiation process with the federal center eventually agreed to a compromise decision: signing the Federal Treaty with Moscow in 1994 in exchange for widening its autonomy powers in the Russian Federation.

8 Viva Ona Bartcus, The Dynamic of Secession (Cambrigde: Cambridge University Press, 2004), 18. 


\section{Structural Prerequisites of Chechen Separatism}

The Chechen-Ingush Autonomous Soviet Socialist Republic (ASSR) was a small republic with a population of about 1.2 million in 1989. The territory of Chechnya (15,0oo square $\mathrm{km}$ ) is located along the Northern slopes of the Caucasus Mountains. Across the mountains to the south this republic borders with Georgia, making the geographic location of the Chechen Republic highly favorable for secession in comparison to such autonomous republics within the Russian Federation as Tatarstan or Bashkortostan, which are surrounded by the territory of Russia. This makes these republics extremely vulnerable in case of possible secessionist attempts on their part. ${ }^{9}$

The proximity of the territory of Chechnya to the Caspian Sea as well as the intersection of strategic trade, transport, and pipeline routes on the territory of Chechnya make this a region of strategic importance for the economic and geopolitical interests of the Russian Federation.

Along with considering the national and social structure of the Chechen-Ingush Republic (ASSR) on the eve of their secessionist aspirations in the early 1990s, it is worth mentioning that the majority of inhabitants of the Republic were ethnic Chechens, with Russians - concentrated mainly in the capital city of Grozny and the region north of the Terek river (the Nadterechnyi district) - making up at least a quarter of the total population..$^{10}$ Besides, according to the 1989 census, the Chechen-Ingush Republic of the RSFSR had the second highest concentration of members of the titular nationality in the population (70.7\%).1 Also, despite the durable policy of Russification in the Soviet period, and the mass deportations of Chechens in 1944 to the Central Asia region, Chechnya preserved a strong affinity for the Chechen language, having the highest proportion (among all other autonomous republics) of those who considered this language as the "native" language of everyday communication..$^{22}$ Of a total population of almost 9oo,ooo Chechens, only $1 \%$ considered Russian to be their mother tongue. ${ }^{13}$ Actually, despite the inflows of Russians in the 1950s, and attempts to dilute the Chechen ethnos after the rehabilitation of 1957 through the extension of the Republic's territory with mostly Russian populated southern districts of the Stavropol Krai, Chechens were not assimilated and managed to preserve their distinguishing ethnic features, among which religion (Islam) and the native language allegedly played the crucial role.

However, it would be incorrect to overestimate the ethnic unity of Chechens as a kind of coherent well-defined nation. As Mike Bowker claims, "Chechnya was small and had never been a nation-state being instead a part of greater union — Caucasian or Russian." 14 Their affinity with the neighboring Ingush people as a part of the "Vainakh" brotherhood also partly undermined the

9 Monica Duffy Toft, The Geography of Ethnic Violence: Identity, Interests, and the Indivisibility of Territory (Princeton: Princeton University Press, 2003), 64.

10 Mike Bowker, "Russia and Chechnya: The Issue of Secession," Nations and Nationalism 10.4 (2004): 466.

11 Gail W. Lapidus, “Contested Sovereignty: The Tragedy of Chechnya," International Security 23.1 (1998): 10.

12 Lapidus, “Contested Sovereignty," 10.

13 Tracey German, Russia's Chechen Wars (London: Routledge Curzon, 2003), 19.

14 Bowker, "Russia and Chechnya: The Issue of Secession," 465. 
idea of a coherent Chechen nation. Moreover, the Chechen people were, according to Bowker, always divided along ethnic, clan and religious lines..$^{15}$ Chechens historically displayed especially strong affiliation within family clans, called teyps, which was later considered as a substantial obstacle in constructing a broader identity of the "Chechen nation" and enhancing it as the basic national identity of the Chechen people.

An important point in the discussion on Chechen ethnic peculiarities is provided by renowned Russian ethnologist Valery Tishkov, who claims that the "Chechens' cultural similarity to the rest of Russia's population, to ethnic Russians and North Caucasians in particular, was far greater than their difference from them." 16 Tishkov asserts that "Sovietization" substantially undermined religiousness in "Islamic republics" as well as in other republics, bringing up mainly atheists. ${ }^{17}$ The future leader and president of the independent Chechen Republic (Ichkeria) Dzhokhar Dudaev (1944-1996) was the most expressive product of this Sovietization process, as he was an atheist officer before gaining power in Chechnya. Apart from some ritual mentions of Islam, Chechens did not identify themselves as "Islamic peoples," and that is why American sociologist Georgi Derluguian claims that there was no ground for using the Islamic religion to explain the extremely strong national consciousness among Chechens. ${ }^{18}$

The socioeconomic situation in the Chechen Republic before the secessionist uprising of 1991 was extremely problematic and built-in social inequalities played a crucial role in exacerbating center-periphery tensions, as well as favoring an ethno-nationalist and later secessionist uprising. Dr. Julia Grigorieva believes that the structural socio-economic problems of Chechnya actually lay at the root of the ethno-political conflict in the Caucasian Republic. ${ }^{19}$ Emerging out of the disintegrating Soviet Union, Chechnya at that time suffered an unemployment rate of some $40 \% .^{20}$ The lack of employment was a serious problem especially for rural dwellers who were mainly ethnic Chechens. ${ }^{21}$ Tracey German mentions that "native Chechens were severely underrepresented in white-collar occupations [...] as well as in the republican extraction and refining industry, machinery manufacture, transport, and administration." ${ }^{22}$ Actually such a situation in the republican employment structure seemed to be rather disturbing as ethnic Chechens had grounds to claim themselves as being socio-economically discriminated in their "own" republic.

15 Bowker, "Russia and Chechnya: The Issue of Secession," 465.

16 Valery Tishkov, Chechnya: Life in a War-Torn Society (Berkeley, CA: University of California Press, 2004), 10

17 Tishkov, Chechnya: Life in a War-Torn Society, 10.

18 Georgi M. Derluguian, Chechnya and Tataria (Washington D. C.: U. S. Institute of Peace, 1997), 210.

19 German, Russia's Chechen Wars, 22.

20 Matthew Evangelista, The Chechen Wars: Will Russia Go the Way of the Soviet Union?

(Washington D. C.: Brookings Institution Press, 2003), 20.

21 Edward W. Walker, "Negotiating Autonomy: Tatarstan, Asymmetrical Federalism, and State Consolidation in Russia," in Separatism: Democracy and Disintegration, ed. Metta Spencer (Lanham, MD: Rowman and Littlefield, 1998), 240. 
As subsequent events have shown, radical nationalists effectively manipulated the above mentioned structural shortcoming in their struggle for the Chechen Republic's self-determination. In addition to that another important point is made by Chechen academic, Professor Dzhabrail Gakaev, who argues that "Chechens were deliberately excluded from taking an active role in the government and administration in the republic." ${ }^{23}$ This in turn, as we might assume, could have substantially contributed to the lack of a competent political elite and intelligentsia in the Chechen Republic in the period of state-building after secession.

The presence of economic discrimination was also tangible in the average levels of income and general standards of living in the Chechen-Ingush ASSR prior to the breakdown of the USSR. For instance, in 1985 the average monthly wage in the Republic was estimated at 158 rubles compared to the RSFSR's average of 199 rubles, and this gap even widened by 1991 when the average wage in the Chechen Republic was only 392 rubles as opposed to the 548 rubles in the RSFSR. ${ }^{24}$ Sufficient crises trends were explicit in the oil extraction and refinement industry of the region: the production of oil was in a steady decline from a peak production of 21 million tons to only 4 million tons in $1991 .^{25}$

The economic problems associated with the decline in industry production, low wages, and the rather high unemployment rate in the then Chechen-Ingush ASSR have been exacerbated even more by the steadily growing birth rate and respectively - growing population density among ethnic Chechens. ${ }^{26}$

The data provided above clearly show the tenseness of the socioeconomic situation in the Chechen-Ingush ASSR, especially with regard to those representing "titular ethnicity" in the Republic. Structural unemployment, extremely high among ethnic Chechen rural citizens, the underrepresentation of ethnic Chechens in the spheres of skilled labor (the oil industry, machinery etc.), segregation in the administrative and governmental domains, which were absolutely dominated by Moscow-appointed Russian bureaucrats, the underdeveloped infrastructure in the region - all these factors apparently had long-lasting implications for the further development of the political situation in the Chechen Republic.

First of all, ethnically predetermined employment ${ }^{27}$ contributed substantially to creating deep social cleavages in the Chechen Republic: north versus south, highland (Chechen) versus lowland (Russian); industrial/agricultural settled versus mountain-pastoral; Russified versus indigenous cleavages. ${ }^{28}$ These cleavages even deepened the alienation between "titular" Chechens

23 German, Russia's Chechen Wars, 21.

24 Rossiiskii statisticheskii yezhegodnik, 1994 [Russian Statistical Annual, 1994] (Moscow: Finansy i statistika, 1994), 513-14.

25 Evangelista, The Chechen Wars: Will Russia Go the Way of the Soviet Union, 20.

26 Vladimir Grivenko, "O chislennosti naseleniia Chechni v iiule 1999 (k nachalu novogo kavkazskogo konflikta) [On Population Statistics in Chechnya in July 1999 (to the Beginning of the New Conflict in the Caucasus)]," accessed December 1, 2016, http://www.memo.ru/hr/hotpoints/n-caucas/ habitants.htm.

27 Ethnic Russians dominated in industry, machinery, as well as in the administration of the ChechenoIngush ASSR at the time.

28 Hughes, "Chechnya: The Causes of a Protracted Post-Soviet Conflict," 19. 
and Russians in Chechnya, making their socioeconomic interests non-negotiable or even opposing. Acute socioeconomic problems created a powerful potential for discontent among citizens of the Autonomous Republic, especially among ethnic Chechens who felt themselves much more discriminated against in "their own" Republic.

A lack of professional qualification and education among many rural Chechens apparently also made them quite susceptible to the populist mottos and promises made by the leaders of the ethno-nationalist movement, who have skillfully manipulated public opinion playing the "ethnic card." Lastly, the clear intersection of ethnic and socioeconomic cleavages illustrated above created a rather fertile ground for those radical nationalist politicians, activists, and leaders of the Chechen people who were inclined to blame Russians for the economic hardships of ethnic Chechens, and argued therefore the necessity of independence through full secession from the RSFSR.

\section{The Changing Equilibrium of the Costs and Benefits of Secession}

\section{The Rise of the Nationalist Movement and the Independence of Chechnya}

The new democratization policies of perestroika and glasnost under the presidency of Mikhail Gorbachev created an atmosphere that was highly conductive for local political elites in the regions seeking more power and influence in contrast to the omnipotent center in Moscow. In order to consolidate power on the local level republican political elites manipulated the idea of more self-determination for regions, which turned out to be rather attractive for the citizens of these regions and republics. As Russian ethnologist Valery Tishkov stated about that period of growth of self-determination tendencies: "Ethnic nationalism gradually began to emerge as a foundation for a political platform." ${ }^{29}$ Under the liberalization tendencies of perestroika at the end of the 1980s plenty of national organizations and fronts emerged, which gradually loosened and eventually undermined the monopoly of the powerful Communist party and nomenklatura in the USSR. Acting on either the local or republican levels, these new-born political and civic forces sought to mobilize public support through exploiting inter alia the issues of ethnicity and national self-determination.

The Chechen-Ingush ASSR did not remain aside of the All-Union tendencies evolving in a variety of administrative units and republics of the Soviet Union. The local political elite, led by ethnic Chechen Doku Zavgaev, first secretary of the Republic's Communist party since 1988, tried to move cautiously in seeking more rights from the Center. In contrast to this moderate republican political elite, a political wing in the Republic that sought to accelerate the process of self-determination and declared a much more radical political agenda evolved. ${ }^{30}$ Two events were crucial at the initial phase of the development of the nationalist movement in the ChechenIngush Autonomous Republic: the creation of the Vainakh Democratic Party and the organization of the First Congress of the Chechen People (OKChN) on November 25, 1990 under the leadership

29 Hughes, "Chechnya: The Causes of a Protracted Post-Soviet Conflict," 48.

30 John B. Dunlop, Russia Confronts Chechnya: Roots of a Separatist Conflict (Cambridge: Cambridge

University Press, 1998), 102. 
of nationalist representatives of the republican intelligentsia: Zelimkhan Yandarbiev, Yusup Soslambekov, Beslan Gantemirov, and Yaragi Mamodaev. ${ }^{31}$

The newly created national political forum raised national issues and moved forward a rather radical political agenda in comparison to that pursued by the republican communist elite under the leadership of Doku Zavgaev. The Congress of the Chechen People (OKChN) initially oriented itself on protecting the "national rights" of the Chechen people confronting the national problems of the Chechen people such as discrimination. The pressure created by the Congress of the Chechen People $(\mathrm{OKChN})$ pushed the gradualist nomenclature towards more serious steps on the way towards republican self-determination. Thus, when the Chechen National Congress passed a resolution of state sovereignty in 1990, Chechnya's Republican Supreme Soviet later did the same, also declaring the sovereignty of the Chechen ASSR, one of the last of the autonomous republics of the RSFSR to do so. ${ }^{32}$

The National Congress of the Chechen People held in July 1991 under leadership of the former Soviet military General Dzhokhar Dudaev adopted a declaration

proclaiming Chechnya separate from both the USSR and the RSFSR, at the same time declaring the executive committee of the OKChN headed by Dudaev as the only legal organ of power in the Chechen Republic. ${ }^{33}$

The powerful trigger factor in the irrepressible secessionist drive of the Chechen Republic under Dudaev was the unsuccessful coup of August 1991 in Moscow. This crucial for Soviet history event provoked mass demonstrations in the Chechen Republic at that time and finally delegitimized the local communist elite underDoku Zavgaev, who maintained a rather ambiguous position during the August 1991 Moscow coup.

It is worth mentioning that the seizure of power by Dudaev in 1991 occurred not without the help of Russian President Boris Yeltsin and parliament speaker, ethnic Chechen Ruslan Khasbulatov, who assisted the "self-determination of the Chechen national elite" against the revanchist communist elite under the leadership of Doku Zavgaev. ${ }^{34}$ The position of Moscow and Yeltsin personally changed drastically when his protracted competition for power with Gorbachev lost its relevance and the determination of Dudaev to fully secede from the jurisdiction of the RSFSR (then Russia) became absolutely obvious. But at that stage of the secessionist dynamic in Chechnya it was too late to try to prevent the clear intent of the new Chechen political elite under Dudaev from creating an "own" independent state. 


\section{Ethno-Nationalist Discourse and the Benefits of Secession}

The impetuous rise of the radical nationalist elite under the leadership of Dudaev that finally brought the Chechen Republic to secede from the Russian Federation (RSFSR) would not be possible without the broad public support of such a step by ethnic Chechens who inter alia legitimized with their votes the election of Dzhokhar Dudaev in October 1991 as President of the self-proclaimed Chechen Republic. The turnout at the presidential elections was about $72 \%$ (458,144 voters), among whom 9o\% allegedly supported the candidacy of Dudaev. ${ }^{35}$ How was it possible to achieve such strong popular support for the nationalists seeking secession?

It might be assumed that the crucial role in uniting Chechens around the idea of the necessity to secede from Russia was the formation of a specific ethno-nationalist discourse in the Chechen Republic at the time. An important element of this discourse was the idea that Chechens would be better off economically and politically only by being fully independent from the Russian Federation. It was stated repeatedly that Chechens are discriminated against in all spheres of social, economic, and political life, and it was only through independence and the creation of fair conditions for the "titular ethnos" that many of the hardships of Chechens could be overcome.

According to Moshe Gammer, Chechen authorities, the national movement, and in fact the entire Chechen intelligentsia (mainly historians) have been involved in the "revision of their national past and rewriting of their history on both the academic and popular levels." ${ }^{36}$ The author goes further with the statement that "the new version of the Chechen past has had to tackle two challenges: the immediate, political need to justify independence and counter the Russian arguments - legal and other - against secession." ${ }^{37}$

The justification of the necessity to secede also found its roots in the collective trauma of the deportations of 1944 under Stalin, which was actively discussed on the eve of the Chechen self-determination struggle in 1991. For many Chechens at that time the collective trauma of deportation was a key formative experience that was used by the new nationalist political elite as a vivid confirmation of the rather "high costs" (see — risks) of being further a part of Russia. ${ }^{38}$ The revival in historical memory at that time of the Caucasus Wars (1817-1864) of the 19th century with the Russian Empire was also a powerful factor that consolidated the Chechen people around the idea of independence against the "aggressive colonizer" that is Russia. Sergei Artiunov argues that the new historical accounts strengthened in the public discourse of the Chechen Republic the idea of historically conditioned "ethnic enmity" between Russians and Chechens, which in the perception of many ethnic Chechens allegedly made the very possibility of further common

Dzhohar Dudaev, Ternistyi put k svobode [The Thorny Path to Freedom] (Vilnius, 1993), accessed December 1, 2016, http://chechenlaw.ru/?p=433.

36 Moshe Gammer, "Nationalism and History: Rewriting the Chechen National Past," in Secession, History and the Social Sciences, ed. Bruno Coppieters et. al. (Brussels: VUB Brussels University Press, 2002), 118.

37 Gammer, "Nationalism and History," 118.

38 Lapidus, "Contested Sovereignty: The Tragedy of Chechnya," 9. 
coexistence with Russia in one state hardly acceptable because of the great risks of further confrontation. ${ }^{39}$

Trying to construct a de-Sovietized Chechen identity and history, local nationalist elites (and later authorities) according to Moshe Gammer, have been drawing Chechen national tradition and roots from pre-Soviet and pre-Russian layers - Islamic and even pre-Islamic. ${ }^{40}$ The logic of this new national narrative building was to reinforce the idea that "the Chechens have never been submitted to Russian rule," and that accordingly secession from the Russian state should not be regarded as secession per se. ${ }^{41}$ Building the ethno-nationalist discourse around the idea of Russian colonialism of the 19th century and permanent Chechen resistance to it (since the times of the Caucasus Wars); revival of the still painful collective trauma of the deportations in 1944 committed by the Soviet regime under Stalin, and producing the discourse of historical independence of the Chechens from Russian rule - all these were powerful elements which nationalist political elites under Dudaev instrumentalized with the aim of establishing the "Chechen nation." It also helped them in persuading post-Soviet ethnic Chechen society in the necessity of moving towards full self-determination (secession), because further membership in the Russian Federation might be of a "high cost" for them.

The ethno-national discourse elaborated by the new political elites of Chechnya was substantially strengthened with ideas of the significant benefits that independence of the Chechen Republic might bring for ethnic Chechens living under the pressure of difficult structural socioeconomic conditions at the time. The narrative of a prosperous independent future of Ichkeria was widely extended through the public statements of President Dzhokhar Dudaev and his political allies. They were convinced and tried to persuade their citizens that Chechnya could become a "Caucasian Kuwait" because of its high-quality oil reserves and petroleum-processing infrastructure..$^{42}$ Dudaev claimed that ethnic Chechens were "blocked from access to jobs and resources," ignoring the realities of high labor market competition and the lack of competent Chechens to be employed in "white-collar" jobs in the republic at the time. ${ }^{43}$ The very fact that mostly ethnic Russians worked in the oil-industry and machinery gave republican nationalists led by Dudaev a favorable ground to blame Moscow for creating discriminative policy regarding titulars (ethnic Chechens), who were not fully participating in the industrialized economy of "their" own republic. ${ }^{44}$ Overcoming economic discrimination and injustice by providing Chechens with good job positions and promoting the economic interests of the "titular nation" were declared to be key priorities of the new national elite and the newly elected president, D. Dudaev. in the Caucasus, ed. Fred Wehling (San Diego: Institute on Global Conflict and Cooperation, University of California, 1995), 17. Gammer, "Nationalism and History: Rewriting the Chechen National Past," 119-20. Gammer, "Nationalism and History: Rewriting the Chechen National Past," 121. Robert Schaefer, The Insurgency in Chechnya and North Caucasus: From Gazavat to Jihad (Santa Barbara: Praeger Security International, 2010), 111. 
Returning "the Chechen economy to Chechens" - that was a rather manipulative message that nevertheless gained widespread support among ethnic Chechens seeking for a rapid solution of their acute economic problems. General Dudaev, as M. Evangelista argues, "tended to exaggerate the economic benefits that would accrue to an independent Chechnya" and repeatedly claimed that oil-rich Chechnya would be better off economically as an independent state. ${ }^{45}$

\section{The Weakening Center and the Costs of Secession}

Another important factor that could have substantially facilitated Chechen independence aspirations was the position taken by the Center (Moscow) precisely throughout the period when nationalist elites were step by step asserting their influence and authority in Chechnya. It might seem that the nationalist elites in Chechnya in 1991 were not concerned that much with a possible suppression of their local activities by a weakening Moscow center. This became especially clear when the legitimacy of Soviet governmental authorities was substantially undermined by the Moscow events in August 1991, when the reactionary coup known as the GKChP was defeated.

One could also note that Chechen national movements (mainly The National Congress of Chechen People) did not have much reasons to feel themselves restrained or limited by the repressive apparatus of the Center, but rather on the contrary: on the eve of the Soviet Union's breakup they, among other republican elites, were even instigated by the then President of the RSFSR, Boris Yeltsin, "to take as much sovereignty as they could swallow."46

Besides, Yeltsin together with the then Chairman of the Supreme Council of the RSFSR, Ruslan Khasbulatov, supported the new nationalist elites of the Chechen-Ingush ASSR in their confrontation with the Chechen republican communist elites under the leadership of Doku Zavgaev. This support was especially due to the protracted conflict simultaneously taking place on the central political scene between Mikhail Gorbachev and Boris Yeltsin.

In any case, this kind of confrontation in Moscow might have contributed significantly to the formation of a specific political perception among local republican elites. The latter perceived the Center in Moscow as unconsolidated, having a power diarchy with one power branch (Yeltsin) even providing "generous promises" of more sovereignty and self-determination for them.

Generally, the situation of a power duality during Yeltsin's and Gorbachev's rivalry weakened Moscow (the Center) in its ability to control or prevent secessionist aspirations growing in autonomous subjects and republics. This explicit connivance of Moscow with regard to growing Chechen separatism in its turn gave local nationalist elites under the leadership of Dudaev the ability to act decisively in promoting their radical political agenda, evolving from self-determination to the idea of outright secession from Russia. That was exactly the process where a "metropolitan weakness encouraged peripheral secessionists," as it was accurately noted by James Hughes in his article. ${ }^{47}$

45 Evangelista, The Chechen Wars: Will Russia Go the Way of the Soviet Union, 4.

46 Andrew Felkay, Yeltsin's Russia and the West (Westport, CT: Greenwood Publishing, 2002), 46. 


\section{Conclusion}

Applying the theoretical approach of Viva Ona Bartcus, based on evaluating the costs and benefits of secession (as well as the costs and benefits of membership in the host-state), it was empirically proved that the rise of the nationalist movement and ethno-nationalist discourse in Chechnya was conducive to the changing perception of possible benefits that secession from the Russian Federation might bring for Chechnya. The revival of historical memory and the collective trauma of the deportations in 1944 in the nationalist discourse at the same time substantially raised the perception of costs which the republic allegedly would have paid if it would further remain being a part of Russia. The relationship between Moscow and regional elites in Chechnya demonstrated the weakening position of the Center that was perceived by nationalist elites as a sign of reducing the costs of possible secession. The structural prerequisites for secession as it was explained in the article - mainly the economic problems and the discontent the Chechen people associated with it were effectively played out by nationalist elites in their struggle for self-determination. To sum up, Chechen secession resulted from the changing equilibrium in cost-benefit balance when the social and economic benefits of secession were exaggerated in public discourse among the Chechen people; costs of further membership in Russia, expressed mainly through the idea of the "Russian threat," were substantially enlarged and the costs of secession were definitely reduced as a result of the weakening position of the Moscow-based central authorities.

At the current stage the Chechen Republic does not seem to be seeking secession from Russia, as the leader of the Republic, Ramzan Kadyrov, extracts substantial benefits from his Republic being formally a part of the Russian federal state. On the one hand, Kadyrov holds the powers which no other regional leader in Russia possesses (for instance, he has his own militia), on the other - the budget of Chechnya is formed primarily by direct financial transactions from Moscow and other inflows from the central government, which were not affordable for Russia in the early 199os. Thus, the current status quo in the relations of Moscow and Grozny seems not to significantly motivate regional authorities in Chechnya for launching another secessionist struggle, due to its dubious benefits and potentially extremely high costs.

\section{Bibliography}

Artiunov, Sergei. "Ethnicity and Conflict in the Caucasus." In Ethnic Conflict and Russian Intervention in the Caucasus, edited by Fred Wehling, 15-19. San Diego: Institute on Global Conflict and Cooperation, University of California, 1995.

Bartcus, Viva Ona. The Dynamic of Secession. Cambrigde: Cambridge University Press, 2004.

Bowker, Mike. "Russia and Chechnya: The Issue of Secession." Nations and Nationalism 10.4 (2004): 461-78.

Grivenko, Vladimir. "O chislennosti naseleniia Chechni v iiule 1999 (k nachalu novogo kavkazskogo konflikta) [On Population Statistics in Chechnya in July 1999 (to the Beginning of the New Conflict in the Caucasus)]." Accessed December 1, 2016. http://www.memo.ru/hr/hotpoints/ n-caucas/habitants.htm.

Cornell, Svante E. "Autonomy as a Source of Conflict: Caucasian Conflicts in Theoretical Perspective." World Politics 54.2 (2002): 245-76. 
Derluguian, Georgi M. Chechnya and Tataria. Washington D. C.: U. S. Institute of Peace, 1997.

Dudaev, D. Ternistyi put k svobode [The Thorny Path to Freedom]. Vilnius, 1993.

Dunlop, John B. Russia Confronts Chechnya: Roots of a Separatist Conflict. Cambridge: Cambridge University Press, 1998.

Evangelista, Matthew. The Chechen Wars: Will Russia Go the Way of the Soviet Union? Washington D. C.: Brookings Institution Press, 2003.

Felkay, Andrew. Yeltsin's Russia and the West. Westport, CT: Greenwood Publishing, 2002.

Gammer, Moshe. "Nationalism and History: Rewriting the Chechen National Past." In Secession, History and the Social Sciences, edited by Bruno Coppieters and Michel Huysseune, 117-40. Brussels: VUB Brussels University Press, 2002.

German, Tracey. Russia's Chechen Wars. London: Routledge Curzon, 2003.

Giuliano, Elise. "Secessionism from the Bottom-Up: Democratization, Nationalism, and Local Accountability in the Russian Transition." World Politics 58.2 (2006): 276-310.

Giuliano, Elise. Constructing Grievance: Ethnic Nationalism in Russia's Republics. Ithaca, NY: Cornell University Press, 2011.

Hale, Henry E. "The Parade of Sovereignties: Testing Theories of Secession in the Soviet Setting." British Journal of Political Science 30.1 (2000): 31-56.

Horowitz, Donald. "Irredentas and Secessions: Adjacent Phenomena, Neglected Connections." International Journal of Comparative Sociology 32.1-2 (1992): 118-30.

Hughes, James. "Chechnya: The Causes of a Protracted Post-Soviet Conflict.” Civil Wars 4.4 (2001): $11-48$.

Lapidus, Gail W. "Contested Sovereignty: The Tragedy of Chechnya." International Security 23.1 (1998): 5-49.

Pavkovic, Aleksandar, and Peter Radan. The Ashgate Research Companion to Secession. Burlington: Ashgate Publishing Company, 2001.

Rossiiskii statisticheskii yezhegodnik, 1994 [Russian Statistical Annual, 1994]. Moscow: Finansy i statistika, 1994.

Schaefer, Robert W. The Insurgency in Chechnya and North Caucasus: From Gazavat to Jihad. Santa Barbara: Praeger Security International, 2010.

Tishkov, Valery. Chechnya: Life in a War-Torn Society. Berkeley, CA: University of California Press, 2004.

Toft, Monica Duffy. The Geography of Ethnic Violence: Identity, Interests, and the Indivisibility of Territory. Princeton: Princeton University Press, 2003.

Walker, Edward W. "Negotiating Autonomy: Tatarstan, Asymmetrical Federalism, and State Consolidation in Russia." In Separatism: Democracy and Disintegration, edited by Metta Spencer, 227-52. Lanham, MD: Rowman and Littlefield, 1998.

Ruslan Kermach is a postgraduate student of the Political Science Department at the National University of Kyiv-Mohyla Academy and a political analyst at the Ilko Kucheriv Democratic Initiatives Foundation (DIF), a Kyiv-based think tank. He received MA in Political Science in 2014 
and graduated from NaUKMA with honors. In 2013-2014 he received a DAAD (German Academic Exchange Program) scholarship for a semester of study at the Friedrich-Schiller University of Jena, Germany. Since then Ruslan Kermach has studied frozen conflicts, issues of secessionism, and de facto statehood in post-Soviet space. He actively participates in seminars, academic conferences, and round-tables in Ukraine as well as abroad, devoted to these subjects. In 2016 Ruslan Kermach was chosen as a grantee of the Democracy Fellowship provided by PASOS (Policy Association for an Open Society) to conduct research on the Transnistrian unrecognized de facto state in the Republic of Moldova. 